\title{
Recruitment and communication of food source location in three species of stingless bees (Hymenoptera, Apidae, Meliponini) ${ }^{1}$
}

\author{
Ingrid AGUILAR $^{\mathrm{a} *}$, Alicia FonSECA ${ }^{\mathrm{a}}$, Jacobus C. BIESMEIJER ${ }^{\mathrm{b}}$ \\ a Centro de Investigaciones Apícolas Tropicales, Universidad Nacional, PO Box, 475-3000 Heredia, \\ Costa Rica \\ ${ }^{\mathrm{b}}$ School of Biology University of Leeds, Leeds LS2 9JT, UK
}

Received 26 July 2004 - Revised 28 September 2004 - Accepted 28 September 2004

Published online 1 June 2005

\begin{abstract}
This study reports on controlled experiments of the recruitment behavior and location communication in three species of stingless bee Trigona corvina, Plebeia tica and Trigona (Tetragonisca) angustula. We trained bees to a sugar water feeder at $50 \mathrm{~m}$ and placed identical control feeders either at different distances or in different directions with respect to the nest. Both the distance and direction of the food source were communicated very accurately in T. corvina. In P. tica and T. angustula the direction of the food source was communicated. In the distance experiments with $P$. tica, newcomers arrived mostly at the food source nearest to the nest. Only when the control feeder had a different odor than the experimental feeder did most recruits find the experimental feeder. We found that experienced foragers of $T$. corvina and $P$. tica guide recruits to the food source by means of pilot flights. We discuss the potential mechanisms that these species may use for location communication and the implications of these differences for resource partitioning.
\end{abstract}

communication / recruitment / pilot flights / stingless bees / Trigona / Plebeia

\section{INTRODUCTION}

An important aspect of animal life in social communities is communication between members of the group. Communication facilitates the allocation of tasks within the group and underlies a wide range of highly flexible and adaptive collective behavior, including cooperative hunting, coordinated defense, and group foraging. Social insects are famous for their collective behavior in relation to nest building, migration, defense, and especially foraging. Many social insects collect their food from plants whose flowers provide pollen and nectar for a short period that ranges from a few hours to several days. Generally, multiple plant species are in flower simultaneously, each with different flowering and reward features, which leads to a mosaic of foraging opportunities that are rather ephemeral in nature (Roubik et al., 1995). Moreover, different species of flower visitors compete for these rewards. This is probably the main reason why many species of social insects have evolved special behaviors to facilitate the search for new food sources and the rapid exploitation of the most profitable food sources.

The most famous example of such behavior is the waggle dance of the honeybee (von Frisch, 1967). This ritualized dance indicates the location and distance of the profitable food source from which the dancer just returned. Many bees that follow the dance, e.g. recruits, are able to find that particular food source in

\footnotetext{
* Corresponding author: iaguilar@una.ac.cr
}

${ }^{1}$ Manuscript editor: Stan Schneider 
the field, without getting any additional information outside the nest. Several ants, on the other hand, rely largely or completely on information available in the field, e.g. pheromone trails from the nest to the food source or personal guidance, e.g. tandem running (Hölldobler and Wilson, 1990). Both systems are efficient in leading recruits to the food source.

Food source communication in another group of social insects, stingless bees, consists of a wide range of behaviors that seem to be species-specific and range from largely withinnest communication to largely field-based communication (Lindauer and Kerr, 1958, 1960; Esch et al., 1965; Nieh and Roubik, 1998). An experienced stingless bee forager may communicate the position of the food source inside the nest by means of sound (Esch et al., 1965; Nieh and Roubik, 1998) or in the field by means of scent trails between nest and food source (Lindauer and Kerr, 1958, 1960), scent-marks near the food source (Kerr, 1994), pilot flights from nest to food source (Esch et al., 1965) or a combination of these (Nieh et al., 2003). In addition, the odor of the food source, clinging to the scout bee, provides information on the type of food plant that is exploited.

Controlled studies on the mechanisms and efficiency of location communication in stingless bees were started by Lindauer and Kerr (1958, 1960) and Lindauer (1956) and have recently been taken up by several authors (Nieh and Roubik, 1995; Hrncir et al., 2000; Jarau et al., 2000; Aguilar and Sommeijer, 2001; Aguilar and Briceño, 2002; Breed et al., 2002). Species differ markedly in the communication mechanisms that they use, and thus the comparative approach provides important insights into the behavioural ecology of meliponine foraging communication. This is the main reason why we embarked on a study in which we compare the recruitment efficiency and behavior of several species of stingless bee that are tested under similar conditions.

In this paper we report on three species of stingless bees from Costa Rica: Trigona corvina, Plebeia tica (Wille, 1969) and Trigona (Tetragonisca) angustula. The following questions are addressed for each species: 1 . Do foragers recruit nest mates to a food source? 2 . Is the distance of the food source communicated? 3. Is the direction of the food source communicated? and question 4 , about a possible mechanism of communication: Do scouts guide recruits to the food source by means of pilot flights?

We selected these three species because they represent bees that use different recruitment mechanisms (Johnson, 1983). T. corvina and $T$. (T.) angustula are close relatives, but $T$. corvina, a medium-sized bee with a large colony size (>10000 workers), is an aggressive group forager and may recruit many bees (Johnson and Hubbell, 1974; Johnson, 1983), whereas $T$. (T.) angustula, a small bee with much smaller colonies (generally $<5000$ workers), is regarded a solitary forager (Johnson, 1983) and a poor recruiter (Lindauer and Kerr, 1958). The third species, $P$. tica, is also a small bee with small colonies (probably mostly $<1000$ workers). It might be capable of attracting recruits to a feeder (other Plebeia have been found to do so, e.g. P. droryana (Lindauer and Kerr, 1958)), although Johnson (1983) considers Plebeia foragers to be solitary. Each of these species probably uses mainly field-based mechanisms in recruitment that might include a pheromone trail (probably T. corvina), deposition of a scent beacon near the food source, the odor of the food source, and pilot flights. Scouts of several species of stingless bees guide recruits by partial or complete piloting from the nest to the food source (Lindauer and Kerr, 1958, 1960; Esch et al., 1965; Esch, 1967; Kerr, 1969; Hubbell and Johnson, 1978). Lindauer and Kerr (1958) indicated that pilot flights might be used in combination with scent-marks to guide recruits to a food source (e.g. in T. (Geotrigona) mombuca). Pilot flights have not been reported for the three species studied by us.

\section{MATERIALS AND METHODS}

\subsection{Study site and bee colonies}

The experiments with $T$. angustula were carried out in Horquetas de Sarapiquí $\left(10^{\circ} 20^{\prime} \mathrm{N}, 83^{\circ} 59^{\prime} \mathrm{E}\right)$, and those with $P$. tica and T. corvina at CINAT, Universidad Nacional, Heredia, $\left(10^{\circ} 01^{\prime} \mathrm{N}, 84^{\circ} 07^{\prime} \mathrm{E}\right)$ both in Costa Rica. For each species one colony was used. The $P$. tica colony consisted of about 250 bees and the T. angustula colony of about 1000 bees; both were installed in a wooden observation box. The $T$. corvina colony was left in their natural exposed nest, with a roughly estimated worker population of at 
least 4000 adult bees (because bees were not inhabiting an observation hive, adult population could not be estimated very accurately). Previous studies have confirmed that results from different colonies of the same species are very similar (Johnson, 1983; Biesmeijer et al., 1998; Nieh et al., 2000). Therefore, as in previous studies (e.g. Lindauer and Kerr, 1958; Nieh and Roubik, 1995; Aguilar and Briceño, 2002) we used only a single healthy colony for each of the species in our experiments.

\subsection{Sugar water feeders and training of bees}

The artificial food source consisted of a removable yellow paper plate on a wooden base placed on a $65 \mathrm{~cm}$ high iron stake. Plastic drinking cups were glued to the plate and filled with a $2.0 \mathrm{M}$ peppermint scented $(5 \mu \mathrm{L} / 100 \mathrm{~mL})$ sugar water solution. This solution is more concentrated than most naturally collected nectar to encourage visitation by the bees. We refilled the drinking cups before each observation, after having removed the residue of the old solution. The feeder was placed in front of the nest entrance and moved (with bees on it) to the final position at $50 \mathrm{~m}$ from the nest as soon as one or two bees repeatedly collected sugar water at the feeder. We chose this short distance for testing because these bees are much smaller than honeybees and Melipona stingless bees and also because they have much smaller flight range (Nieuwstadt and Ruano, 1996). Training methods were slightly different for $T$. angustula because foragers could not be trained directly to $50 \mathrm{~m}$. Therefore, we moved the feeder (with bees on it) in small steps to its final position. At each step foragers that kept searching at the old position were brought to the new position by picking them up with a syringe filled with sugar solution.

The trained bees were marked individually with dots of paint on the thorax (water based color that is water resistant when dried up and persists for several days). All unmarked foragers (recruits) arriving at the feeders were captured with a suction tube, put in the refrigerator for a few minutes to slow them down, and then marked green to identify them as recruits and to be able to recognize them on the following days. They were released at the end of the day.

\subsection{Experimental setup}

To study the recruitment effect of individual bees, we allowed only one to three foragers to return from the feeder to the nest in all trials with $T$. corvina and $P$. tica. With $T$. angustula this method did not work; therefore, we used more bees (2-8) per trial. All experiments were performed in the morning of clear days and lasted 30-60 minutes.

To eliminate site bias, we positioned the experimental feeder, i.e. the training feeder, and control feeder in different compass directions in all repetitions. To avoid any effect of scent marks left by the bees, the paper of the control feeder was replaced with a clean one every time a bee landed on it or hovered over it. When an "old recruit" (identifiable by its green paint mark) landed on one of the feeders, it was caught and not counted as recruit. In all experiments, we compared the number of recruits that arrived at the experimental feeder and an identical control feeder. The only difference between the feeders (besides their location) was that trained bees visited the experimental feeder, but not the control feeder. All bees were captured upon arrival at each of the feeders, except for the trained bees. Average wind strengths and direction were obtained from the National Meteorological Institute, Aranjuez station, Costa Rica $\left(09^{\circ} 56^{\prime} \mathrm{N}, 84^{\circ} 05^{\prime} \mathrm{O}\right)$.

\subsection{Distance experiment}

In this experiment we tested whether experienced foragers communicate the distance of a food source to nest mates. To this end, we positioned the control feeder at $5 \mathrm{~m}$ or $40 \mathrm{~m}$ from the nest in the same compass direction as the experimental feeder that was always positioned at $50 \mathrm{~m}$. If distance is communicated, recruits should arrive more often at the experimental feeder than at the control feeder. We performed an additional experiment with $P$. tica in which the control feeder was positioned at $40 \mathrm{~m}$ from the nest and filled with a $2.0 \mathrm{M}$ sugar solution with a different odor $(5 \mu \mathrm{L} / 100 \mathrm{~mL}$ citrus scent) from that of the experimental feeder.

\subsection{Direction experiment}

In this experiment we tested whether experienced foragers communicate the direction of a food source to nest mates. To this end, we positioned the control feeder at the same distance $(50 \mathrm{~m})$ from the nest as the experimental feeder, but in the opposite direction $\left(180^{\circ}\right.$ angle). In a later experiment, the control feeder was located at the same distance $(50 \mathrm{~m})$ from the nest as the experimental feeder, but at an angle of 90 degrees with respect to the experimental feeder. If direction is communicated, recruits should arrive more often at the experimental feeder than at the control feeder. If direction is not communicated, equal numbers of recruits should arrive at both feeders.

\subsection{Calculation of recruitment intensity and efficiency}

To compare recruitment among the species, we calculated the recruitment intensity and efficiency for each species in the distance and direction experiments. Recruitment intensity is the total number of recruits that arrives summed over both feeders for each visit of a trained bee to the feeder. Recruitment 
efficiency is the percentage of all recruits that arrived at the experimental feeder.

\subsection{Pilot flights}

If trained foragers guide recruits to the feeder by means of "pilot flights"; they should arrive at about the same time at the food source (Nieh and Roubik, 1998). To test this, we recorded the arrival times of recruits and trained foragers at the experimental feeder in all experiments ( $T$. corvina and $P$. tica only, because $T$. angustula recruited too few nest mates). Additionally, another series of observations was performed following the same procedure as in the $180^{\circ}$ direction experiment, only without monitoring the control feeder. Overall, piloting was recorded in 11 trials with $T$. corvina and 36 trials with $P$. tica.

For analyses of these data we subtracted the arrival time of the trained bee from the arrival time of the recruit (Nieh and Roubik, 1998). Nieh and Roubik (1998) found for $M$. panamica that $8 \pm 4 \mathrm{sec}$ onds was the smallest difference in the arrival times of recruits with foragers trained to a feeder $100 \mathrm{~m}$ from the nest. Based on this finding, we determined a conservative interval between 4 seconds before and 4 seconds after the trained forager's arrival within which recruits were considered to have arrived simultaneously with the trained bee.

\subsection{Statistics}

We used nonparametric statistical tests throughout because of small sample sizes, non-normal data distributions and unequal variances. We pooled data of multiple trials to calculate a one-tailed binomial test for distance and direction observations (Sokal and Rohlf, 1981; see Nieh and Roubik, 1995). Recruitment measures were compared by means of a Kruskal Wallis test with a multiple comparisons test where appropriate (if more than 2 groups were compared; Siegel and Castellan, 1988) or a MannWhitney U-test (if 2 groups were compared). To analyze the distribution of arrival times of recruits in the pilot flight tests, we used the G-test (Sokal and Rohlf, 1981). All averages are presented as the mean $\pm 1 \mathrm{SD}$. We rejected the null hypothesis when significance tests indicate a one-tailed probability smaller than the critical $\alpha$-level of 0.05 .

\section{RESULTS}

\subsection{Do foragers recruit nest mates to a food source?}

Trained bees of $T$. corvina (colony size more than 4000 bees) recruited on average $3.12 \pm 2.52$

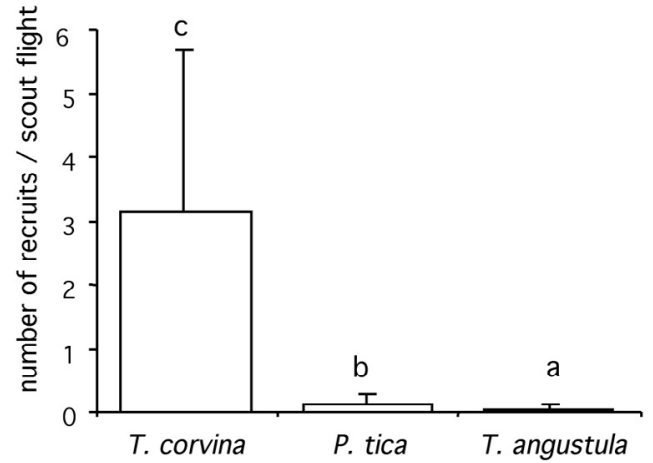

Figure 1. Recruitment intensity, i.e. the number of recruits arriving at both feeders per visit of a trained bee, for three species of stingless bees. Data are pooled from 11 (T. corvina), 33 (P. tica), and 13 (Trigona (Tetragonisca) angustula) trials. The mean $\pm 1 \mathrm{SD}$ is given. The value above each column represents the results of the multiple comparisons test performed after the Kruskal Wallis test showed that not all groups were similar $\left(\chi^{2}=26.14\right.$, $P<0.0001)$

recruits on each visit to the feeder. The recruitment intensity of $T$. corvina was significantly higher than for $P$. tica $(0.11 \pm 0.17$; colony size 250 bees) and was significantly lower in T. angustula $(0.07 \pm 0.04$; colony size 1000 bees) (Kruskal Wallis test: $\mathrm{KW}=26.14$, $P<0.0001$ and multiple comparisons test, see Fig. 1). Recruits of T. corvina arrived in groups of up to 34 bees (Fig. 2b), whereas recruits of $P$. tica mostly arrived alone (Fig. 2a). T. angustula recruited only incidentally and mostly one forager at a time.

Trained bees of $T$. corvina made $6.0 \pm 4.2$ $(n=14)$ visits (which took $15 \pm 16 \mathrm{~min})$ and those of $P$. tica $9.3 \pm 9.0(\mathrm{n}=16)$ visits (which took $24 \pm 18 \mathrm{~min}$ ) before the first recruits arrived, which is statistically not different (Mann Whitney test; number of flights: $\mathrm{Z}=-0.19$, $P=0.85$; time: $\mathrm{Z}=-1.37, P=0.17$ ).

\subsection{Is the distance of the food source communicated?}

In $T$. corvina, almost all recruits arrived at the experimental feeder at $50 \mathrm{~m}$ when the control feeder was placed at $5 \mathrm{~m}$ from the nest (110 of 114 recruits in 2 trials, binomial test with $\mathrm{H}_{0}$ equal probability: $P<0.001$; Fig. 3) and all recruits arrived at the experimental 

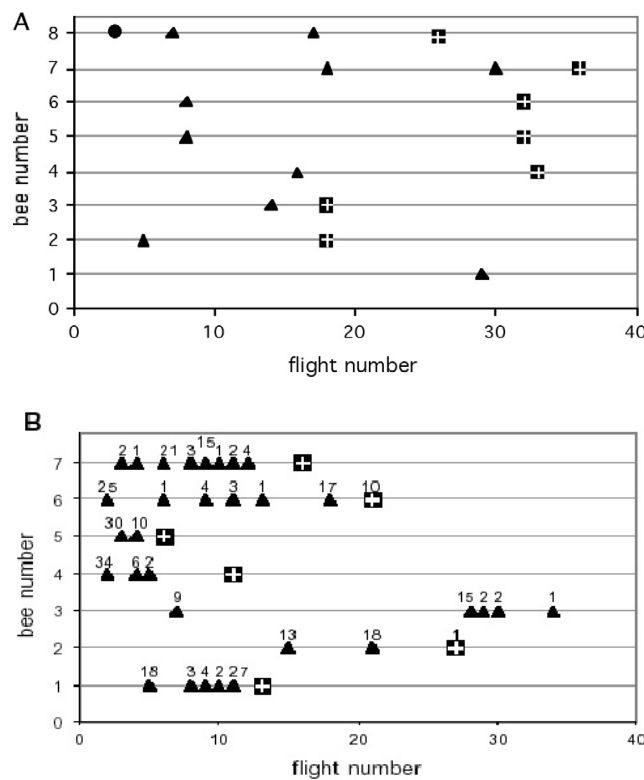

Figure 2. Patterns of recruitment by trained individual bees to a feeder at $50 \mathrm{~m}$ from the nest. Depicted are the first 40 flights of a trained forager to the feeder and for each flight the number of recruits that arrived with the trained bee. Each horizontal line represents the record of a single trained bee. Black squares with a white cross indicate the last flight that was observed for each bee. A. Plebeia tica; a black triangle indicates that a single recruit arrived, a black circle indicates that two recruits arrived. Bee 1 was followed for 74 flights but no recruits arrived after flight 40 . B. Trigona corvina; the numbers above the black triangles indicate the number of recruits that arrived simultaneously with the trained bee on that visit to the feeder. Bee 3 was observed for 43 flights but no recruits arrived after flight 40 .

feeder in experiments with the control feeder at $40 \mathrm{~m}$ from the nest in the same direction $(73$ recruits in 2 trials, binomial test: $P<0.001$; Fig. 3). This shows that the trained bee communicates the distance of the food source to the recruits and that distance communication is very efficient. The efficiency was not different with the control feeder at 5 or $40 \mathrm{~m}$ (Mann Whitney test: $\mathrm{Z}=-1.00, P=0.67)$. In $P$. tica, recruits arrived more often at the control feeder at $5 \mathrm{~m}$ from the nest than at the experimental feeder (16 of 19 recruits at the control feeder in 4 trials, binomial test: $P=0.002$; Fig. 3). However, with the control feeder at $40 \mathrm{~m}$ from the nest, similar numbers of recruits

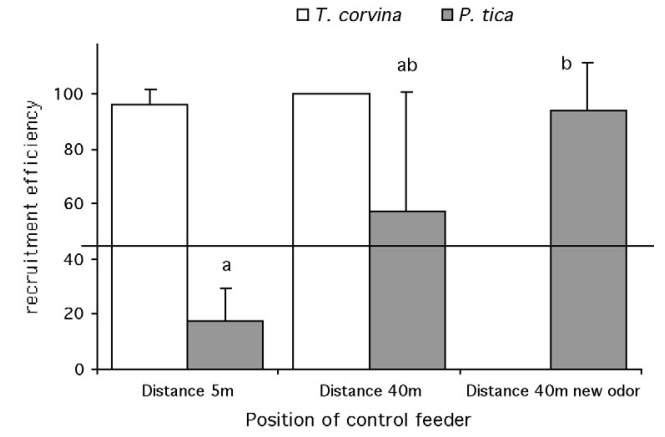

Figure 3. Recruitment efficiency, i.e. percentage of recruits arriving at the experimental feeder, in distance experiments. The experimental feeder was always positioned at $50 \mathrm{~m}$ from the nest and the control feeder was positioned in the same compass direction from the nest, but at either $5 \mathrm{~m}$ or $40 \mathrm{~m}$ from the nest. In additional experiments with $P$. tica, the control feeder was positioned at $40 \mathrm{~m}$ from the nest (and in same compass direction as the experimental feeder), but was scented differently (rightmost column). Given is the mean efficiency per trial \pm 1 SD. We performed $2,4,2,5$, and 8 trials respectively for data in columns from left to right. The letters above the $P$. tica columns indicate the results of the multiple comparisons test performed after the Kruskal Wallis test showed that not all groups were similar $\left(\chi^{2}=10.04, P=0.007\right)$. Efficiency of $T$. corvina was similar in both experiments (Mann Whitney test: $\mathrm{Z}=-1.00, P=0.67)$.

arrived at both feeders ( 9 of 19 recruits at the experimental feeder in 5 trials, binomial test: $P=0.5$; Fig. 3). When we used a control feeder at $40 \mathrm{~m}$ from the nest with the same sugar solution but a different odor, significantly more recruits arrived at the experimental feeder ( 14 of 15 recruits in 8 trials, binomial test $P<0.001$; Fig. 3). A comparison of the three treatments reveals that with the control feeder at $5 \mathrm{~m}$, significantly fewer recruits reach the experimental feeder than with a control feeder of different odor at $40 \mathrm{~m}$ (Kruskal Wallis test: $\chi^{2}=10.04, P=0.007$ with multiple comparison test, Fig. 3). Evidently, P. tica recruits do have information on the odor of the food, but not on the distance of the food source. Moreover, they seem to start searching near the nest and so find the nearby food source much more easily than the experimental feeder located further away. This leads to less accurate recruitment and thus lower efficiency compared to $T$. corvina. In the distance 
experiments with $T$. angustula, too few recruits arrived at the feeders to allow for a statistical analysis.

\subsection{Is the direction of the food source communicated?}

In all three species significantly more recruits arrived at the experimental feeder than at the control feeder placed in the opposite direction (binomial test on pooled data: $P<0.001$ for $T c$ (5 trials) and $P<0.004$ for $P t$ (8 trials), $P=0.006$ for $T a$ (7 trials); Fig. 4). No recruits arrived at the control feeder in any of the trials with $T$. corvina (157 recruits in total), whereas 3 of $18 P$. tica recruits, and 2 of $14 T$. angustula recruits arrived at the control feeder (Tab. I).

When we positioned the control feeder at a $90^{\circ}$ angle with the experimental feeder, significantly more recruits arrived at the experimental feeder than at the control feeder in $T$. corvina and $P$. tica (binomial test on pooled data: both $P<0.001,2$ and 8 trials respectively; Fig. 4).

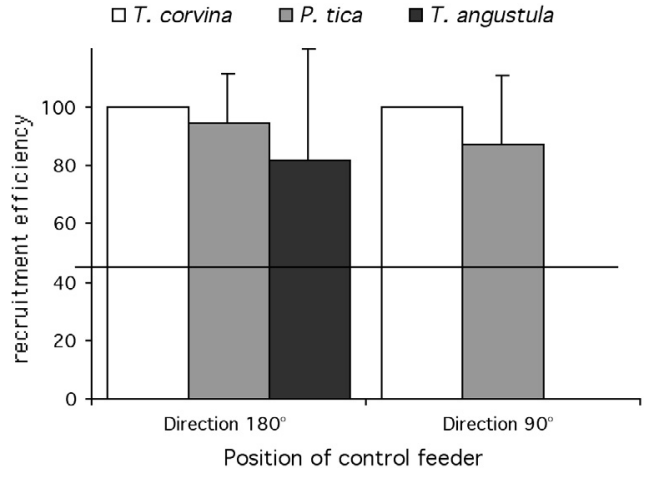

Figure 4. Recruitment efficiency in direction experiments. Both feeders were always positioned at $50 \mathrm{~m}$ from the nest, but in different compass directions such that the angle between the feeders was either $180^{\circ}$ or $90^{\circ}$. The mean efficiency per trial \pm $1 \mathrm{SD}$ is given; $5,9,7,2$, and 8 trials were performed respectively for each column from left to right. Efficiency is statistically similar for all groups (see text for details).

Experimental trials of this kind with T. angustula were unsuccessful.

Table I. Results of experiments testing the communication of distance and direction. The wind direction is given in words. The position of the experimental (Exp.) and control (Ctrl) feeders are given in meters. The average temperature and wind velocity is also given.

\begin{tabular}{|c|c|c|c|c|c|c|c|c|c|c|c|c|c|c|c|c|c|c|c|c|c|}
\hline$\overline{\text { Plebeia }}$ & & & \multirow{2}{*}{\multicolumn{3}{|c|}{ Direction }} & \multirow{3}{*}{$\begin{array}{l}\text { Wind } \\
\text { direction }\end{array}$} & & \multirow{2}{*}{\multicolumn{2}{|c|}{ Average Total }} & \multicolumn{11}{|c|}{ Trigona corvina } \\
\hline & & & & & & & & \multirow{2}{*}{$\begin{array}{c}\text { Averagag } \\
\mathrm{Km} / \mathrm{H}\end{array}$} & & & \multirow{2}{*}{$\frac{\text { Trial }}{\text { Disit }}$} & \multirow[b]{2}{*}{ Date } & \multicolumn{2}{|c|}{ Position } & \multicolumn{3}{|c|}{ Direction } & \multirow{2}{*}{$\begin{array}{c}\text { Wind } \\
\text { direction } \\
\text { de }\end{array}$} & \multicolumn{2}{|c|}{ Average Average } & \multirow{2}{*}{$\begin{array}{c}\text { Total } \\
\text { recruits }\end{array}$} \\
\hline \multirow{2}{*}{$\frac{\text { Trial }}{\text { Distance }}$} & \multirow{2}{*}{ Date } & \multicolumn{2}{|c|}{ Position } & Exp. & Trial tir & & & & $\mathrm{tc}^{\circ}$ & recruits & & & Exp. & $\mathrm{Ctrl}$ & Exp. & Trial time & & & & $\mathrm{tc}^{\circ}$ & \\
\hline & & & & & & & & & & & Distanc & & & & & & & & & & \\
\hline 1 & $26 / 8 / 99$ & 50 & 5 & $\mathrm{~N}$ & 11:30 & 12:00 & none & 3.2 & 26.5 & 5 & 1 & $17 / 3 / 00$ & 50 & 5 & w & 11:55 & $12: 20$ & E & 13.7 & 19.4 & 53 \\
\hline 2 & 30/8/99 & 50 & 5 & $\mathrm{w}$ & 10:00 & 11:00 & $\mathrm{E}$ & 11.5 & 24.5 & 4 & 2 & $17 / 3 / 00$ & 50 & 5 & E & 13:53 & $14: 40$ & $\mathrm{NE}$ & 17.5 & 19.2 & 61 \\
\hline 3 & 18/9/99 & 50 & 5 & $\mathrm{~N}$ & 10:20 & 11:20 & $\mathrm{SE}$ & 11.2 & 22.8 & 6 & 3 & $14 / 3 / 00$ & 50 & 40 & $\mathrm{w}$ & $10: 55$ & $11: 10$ & $\mathrm{NE}$ & 15.1 & 20.2 & 40 \\
\hline 4 & 20/9/999 & 50 & 5 & $\mathrm{~N}$ & $9: 15$ & $10: 15$ & none & 2.9 & 23.9 & 4 & 4 & $17 / 3 / 00$ & 50 & 40 & E & 12:38 & 13:50 & $\mathrm{NE}$ & 15.5 & 19.3 & 33 \\
\hline 5 & $26 / 8 / 99$ & 50 & 40 & $\mathrm{~N}$ & $9: 20$ & $11: 20$ & none & 3.6 & 24.0 & 11 & Directic & n $180 \mathrm{de}$ & rees & & & & & & & & \\
\hline 6 & $30 / 8 / 99$ & 50 & 40 & $\mathrm{w}$ & 8:55 & 10: & $\mathrm{E}$ & 9.0 & 22.4 & 4 & 1 & $24 / 1 / 00$ & 50 & 50 & E & 10:50 & 11:28 & $\mathrm{NE}$ & 17.6 & 23.2 & 54 \\
\hline 7 & 14/9/99 & 50 & 40 & $\mathrm{~N}$ & $9: 27$ & 10:28 & none & 2.9 & 24.6 & 1 & 2 & $14 / 3 / 00$ & 50 & 50 & w & 10:35 & 10:55 & $\mathrm{NE}$ & 16.6 & 21.6 & 42 \\
\hline 8 & $18 / 9 / 99$ & 50 & 40 & $\mathrm{~N}$ & $9: 15$ & $10: 15$ & SE & 11.9 & 21.8 & 1 & 3 & $27 / 7 / 00$ & 50 & 50 & $\mathrm{NE}$ & $10: 20$ & 11:00 & $\mathrm{NE}$ & 14.4 & 22.8 & 34 \\
\hline 9 & 2019/99 & 50 & 40 & $\mathrm{~N}$ & $10: 19$ & 11:20 & $\mathrm{NW}$ & 8.6 & 23.8 & 2 & 4 & $24 / 7700$ & 50 & 50 & $\mathrm{NE}$ & 12:36 & 13:35 & $\mathrm{NE}$ & 13.7 & 23.0 & 12 \\
\hline Distance & e-different & & & & & & & & & & 5 & $28 / 7 / 00$ & 50 & 50 & $\mathrm{NW}$ & 9:52 & 10:31 & $\mathrm{NE}$ & 12.6 & 24.0 & 15 \\
\hline 1 & $24 / 1 / 100$ & 50 & 40 & $\mathrm{~s}$ & $9: 15$ & $9: 46$ & $\mathrm{NE}$ & 15.8 & 21.8 & 2 & Directic & in 90 deg & & & & & & & & & \\
\hline 2 & $25 / 1 / 00$ & 50 & 40 & $\mathrm{~s}$ & $13: 30$ & $14: 00$ & $\mathrm{NE}$ & 19.8 & 21.0 & 1 & 1 & $31 / 1 / 00$ & 50 & 50 & $\mathrm{SE}$ & 13:40 & $15: 12$ & $\mathrm{~N}$ & 19.1 & 22.4 & 33 \\
\hline 3 & $28 / 1 / 00$ & 50 & 40 & $\mathrm{~s}$ & 11:28 & 12:00 & $\mathrm{NE}$ & 16.9 & 19.6 & 1 & 2 & $4 / 2 / 00$ & 50 & 50 & $\mathrm{NE}$ & 9:33 & 11:02 & $\mathrm{NE}$ & 15.1 & 20.9 & 29 \\
\hline 4 & $29 / 1 / 00$ & 50 & 40 & $\mathrm{~s}$ & $10: 15$ & 11:00 & $\mathrm{N}$ & 18.4 & 19.8 & 4 & & & & & & & & & & & \\
\hline 5 & $11 / 2 / 00$ & 50 & 40 & $\mathrm{~N}$ & 9 & $10: 36$ & $\mathrm{~N}$ & 18.7 & 19.2 & 1 & & & & & & & & & & & \\
\hline 6 & $11 / 2 / 00$ & 50 & 40 & $\mathrm{~N}$ & & & $\mathrm{~N}$ & & & & & & & & & & & & & & \\
\hline 7 & $15 / 2 / 00$ & 50 & 40 & $\mathrm{~N}$ & 10 & & $\mathrm{~N}$ & & 20.0 & & & & & & & & & & & & \\
\hline 8 & $15 / 2 / 00$ & 50 & 40 & $\mathrm{~N}$ & 14:10 & $14: 47$ & $\mathrm{~N}$ & 23.0 & 21.4 & 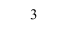 & & & & & & & & & & & \\
\hline Directior & on $180 \mathrm{degr}$ & & & & & & & & & & & & & & & & & & & & \\
\hline 1 & $1 / 9 / 99$ & 50 & 50 & w & $10: 25$ & $11: 25$ & E & 8.6 & 24.0 & 1 & T. angu & & & & & & & & & & \\
\hline 2 & $20 / 12 / 99$ & 50 & 50 & E & $10: 50$ & 11:20 & $\mathrm{NE}$ & 17.6 & 21.4 & 2 & & & Pos & & Directio & & & Wind & Average & Average & Total \\
\hline 3 & 20/10/99 & 50 & 50 & $\mathrm{~s}$ & $10: 16$ & $11: 03$ & NW & 7.9 & 23.3 & 1 & Trial & Date & Exp. & Ctrl & Exp. & Trial time & & direction & $\mathrm{Km} / \mathrm{H}$ & tc. & recruits \\
\hline 4 & $21 / 10 / 99$ & 50 & 50 & $\mathrm{~s}$ & $8: 38$ & $9: 15$ & $\mathrm{SE}$ & 8.3 & 22.7 & 1 & $\overline{\text { Distanc }}$ & & & & & & & & & & \\
\hline 5 & $29 / 10 / 99$ & 50 & 50 & $s$ & $10: 45$ & 11: & NW & 7. & 22 & & 1 & $1 / 6 / 98$ & 50 & 20 & & $8: 15$ & $8: 45$ & none & 3.2 & & 2 \\
\hline 6 & $29 / 9 / 99$ & 50 & 50 & $\mathrm{~N}$ & 10:05 & 11:0 & $\mathrm{N}$ & 8.3 & 23.0 & 4 & 2 & 1 & 50 & 20 & $\mathrm{NW}$ & $9: 34$ & $10: 04$ & $\mathrm{~N}$ & 4.7 & 29.0 & 5 \\
\hline 7 & $30 / 9 / 99$ & 50 & 50 & $\mathrm{~N}$ & $10: 20$ & 10 & NO & 8.6 & 21.4 & 1 & 3 & $1 / 6 / 98$ & 50 & 20 & $\mathrm{NW}$ & $11: 46$ & $12: 16$ & $\mathrm{NE}$ & 7.2 & 29.2 & 2 \\
\hline 8 & $7 / 12 / 99$ & 50 & 50 & $\mathrm{~N}$ & & & ND & ND & ND & 1 & 4 & $30 / 5$ & 50 & 30 & w & 9:30 & & SE & 7.6 & 28.1 & 5 \\
\hline & $29 / 11 / 99$ & 50 & 50 & $\mathrm{~s}$ & $9: 53$ & $10: 55$ & ND & ND & ND & 6 & 5 & $3 / 6 / 98$ & 50 & 30 & NW & $11: 58$ & $12: 28$ & $\mathrm{NE}$ & 9.7 & 31.1 & \\
\hline Directiol & on 90 degre & & & & & & & & & & 6 & $3 / 6 / 98$ & 50 & 30 & $\mathrm{NW}$ & $\begin{array}{l}13: 46 \\
134\end{array}$ & $\begin{array}{l}14: 14 \\
\text { 14. }\end{array}$ & $\mathrm{NE}$ & 10.4 & 31.8 & 1 \\
\hline 1 & $31 / 8 / 99$ & 50 & 50 & w & $9: 4$ & $10:$ & E & 7. & 23.6 & 2 & 7 & $3 / 6 / 98$ & 50 & 30 & NW & 11:22 & 11:52 & $\mathrm{NE}$ & 8.6 & 31.2 & 1 \\
\hline 2 & $2 / 9 / 99$ & 50 & 50 & w & & & $\mathrm{E}$ & & & & irectic & & & & & & & & & & \\
\hline 3 & $17 / 12$ & 50 & 50 & $\mathrm{E}$ & & & $\mathrm{NE}$ & & & 1 & 1 & & 50 & 50 & ES & 10:20 & 10:50 & $\mathrm{N}$ & 7.9 & 29.7 & 4 \\
\hline 4 & $20 / 12 / 99$ & 50 & 50 & $\mathrm{~s}$ & $10: 15$ & 10: & E & 10.8 & 21.6 & 1 & 2 & & 50 & 50 & ES & 11:00 & $11: 30$ & $\mathrm{NE}$ & 7.6 & 29.5 & 4 \\
\hline 5 & $2 / 11 / 99$ & 50 & 50 & $\mathrm{~s}$ & $10: 30$ & 11:00 & NE & 10.8 & 22.0 & 1 & 3 & $10 / 8 / 98$ & 50 & 50 & ES & $11: 40$ & 12:10 & $\mathrm{NE}$ & 10.1 & 28.3 & 2 \\
\hline 6 & $8 / 11 / 99$ & 50 & 50 & $\mathrm{~s}$ & $9: 43$ & $10: 46$ & $\mathrm{NW}$ & 7.2 & 21.7 & 2 & 4 & $14 / 8 / 98$ & 50 & 50 & NW & $10: 20$ & $10: 50$ & $\mathrm{NE}$ & 16.2 & 28.0 & 1 \\
\hline 7 & $13 / 12 / 99$ & 50 & 50 & $\mathrm{~N}$ & $10: 36$ & & & & ND & & & & 50 & 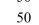 & & $11: 05$ & $11: 35$ & $\mathrm{NE}$ & & & 1 \\
\hline 8 & $30 / 12 / 99$ & 50 & 50 & $\mathrm{~N}$ & $10: 20$ & $10: 50$ & $\mathrm{NE}$ & 17.3 & 17.4 & 2 & 6 & $24 / 8$ & 50 & 50 & $\mathrm{~N}$ & $12: 25$ & $12: 55$ & $\mathrm{NE}$ & 11.2 & 30.5 & 1 \\
\hline & & & & & & & & & & & & $25 / 8 / 98$ & 50 & 50 & NW & $8: 30$ & 9:00 & $\mathrm{SE}$ & 6.2 & 27.1 & \\
\hline
\end{tabular}




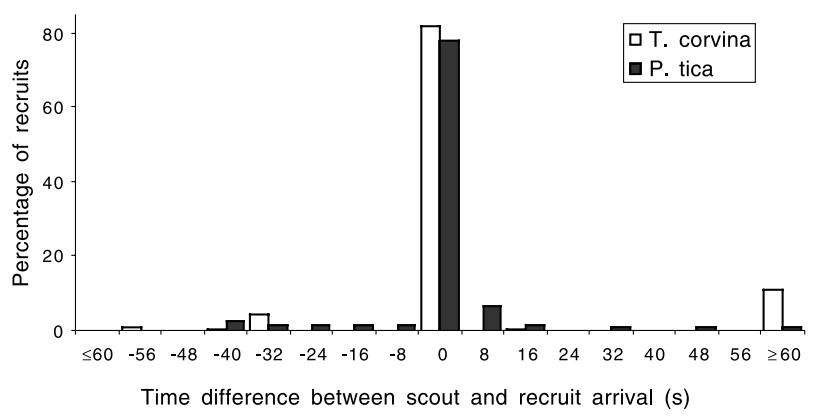

Figure 5. Comparison of arrival times of recruits and trained bees in trials with T. corvina (white columns) and $P$. tica (dark columns). Data are pooled from 11 and 36 trials respectively. Each column represents an eight-second-time interval, except the most extreme column on each side that represents all data more extreme than the value indicated. A time difference of $0 \mathrm{~s}$ (interval from -4 to $4 \mathrm{~s}$ ) represents the recruits that arrived at the same time as the trained bee. Negative values indicate that recruits arrived before the trained bee; positive values indicate that recruits arrived after the trained bee. Total numbers of recruits depicted are 489 for $T$. corvina and 114 for $P$. tica.

The recruitment efficiency was similar in $180^{\circ}$ and $90^{\circ}$ experiments for T. corvina and P. tica (Fig. 4), and also for all three species in the $180^{\circ}$ experiments (Kruskal-Wallis test: $\left.\chi^{2}=1.07, P=0.59\right)$ and both species in the $90^{\circ}$ experiments (Mann Whitney test: $\mathrm{Z}=-1.17$, $P=0.52$; Fig. 4).

\subsection{Are recruits guided by means of pilot flights?}

We recorded the exact arrival times of the trained bees and the recruits in the distance and direction experiments with $P$. tica and $T$. corvina, and additional trials with $P$. tica (In total: T. corvina: 11 trials, $P$. tica: 36 trials). The vast majority of the recruits arrived at the same time, i.e. between 4 seconds before and 4 seconds after the arrival of the trained bee (Fig. 5; P. tica: $78.1 \%$ of 114 recruits; T. corvina: $87.5 \%$ of 489 recruits). Significantly more recruits than expected arrive with the pilot bee (G-test for homogeneity, $\mathrm{H}_{0}=$ equal numbers before, with, and after pilot bee: $T$. corvina, $\mathrm{G}=501.9, P<0.001 ; P$. tica, $\mathrm{G}=98.3$, $P<0.001)$. Arrival patterns are similar in both species (G-test for independence, 3 categories before, with, after arrival of pilot bee: $\mathrm{G}=1.92, P>0.1$ ).

With $T$. corvina, recruits arrived in groups (see also Fig. 2a). The group of recruits gener- ally came flying in right behind the trained bee. The recruits hovered over the feeder table and did not land till the trained bee had landed. A few minutes before landing, the trained bee started making short flights from the feeder into the direction of the cloud of recruits that could be seen at some distance from the feeder table. During this period the trained bee also landed on the soil and vegetation between the recruits and the feeder. She rubbed her mandibles and dragged her abdomen over these substrates, and in doing so she probably left scent-marks (Lindauer and Kerr, 1958). Some recruits from the cloud then landed on these spots and started to perform a similar "scent marking" behavior.

We recorded two groups of recruits (30 and 13 bees) that did not follow a trained bee the entire distance to the food source. It is not known what factor, e.g. strong wind or scout bee got lost, caused these groups to arrive on their own.

The trials with $T$. angustula rendered a total of 30 recruits, of which 11 arrived at the control feeder. This suggests that recruits are not guided to the food source by means of pilot flights. However, we did not record the exact arrival times of the remaining 19 recruits in relation to the arrivals of the small group of trained bees that we used. Therefore, the absence of partial piloting cannot be confirmed. 


\section{DISCUSSION}

\subsection{Recruitment intensity}

All three species recruited newcomers to the feeders. However, recruitment intensity of $T$. corvina was on average 30 times higher than that of $P$. tica and about 45 times higher than that of $T$. angustula (Fig. 1). The $50 \mathrm{~m}$ distance from the nest at which we positioned the experimental feeder is well within the flight range of all three species (Nieuwstadt and Ruano, 1996) and the food source we offered was of very high quality. Therefore, we may assume that our observations accurately represent species-specific differences in recruitment intensity. Relatively low recruitment intensity has been reported for several other species (T. iridipennis; Lindauer, 1956, Tab. III): 0.08 recruits per trained bee flight with feeder at $1 \mathrm{~m}$ distance; $T$. carbonaria (Nieh et al., 2000): 0.27 newcomers per trained bee flight with feeder at $150 \mathrm{~m}$; M. panamica (Nieh and Roubik, 1995): 5 recruits in about 500-1500 trained bee flights with feeder at $100 \mathrm{~m}$ ). Our data confirm the finding of Lindauer and Kerr (1958) that $T$. angustula is a very poor recruiter. Moreover, $P$. tica does only slightly better, which corresponds to $P$. droryana studied by Lindauer and Kerr (1958). Johnson (1983) identifies both T. angustula and a Plebeia species ( $P$. frontalis) as solitary foragers, i.e. poor recruiters. Our data show that $P$. tica is a better recruiter than $T$. angustula, although only single recruits arrived with considerable intervals at the feeder (Fig. 2a). T. corvina, however, is characterized as an 'extirpator' (Johnson, 1983), i.e. a group forager with massive recruitment to a specific place that chases its rivals off the food source. Our study shows, in a controlled experiment, that a single forager of $T$. corvina is capable of recruiting numerous recruits to a food source (Fig. 2b).

\subsection{Direction and distance communication}

The three species we studied differed markedly in their indication of direction and distance of the food source. $T$. corvina communicated distance and direction very precisely. The vast majority of the recruits found the experimental feeder even with the control feeder much closer to the nest (Fig. 3). This behavior is similar to that of T. ruficrus and Scaptotrigona postica (Lindauer and Kerr, 1958; Figs. 6, 7).
Plebia tica, on the other hand, directs most newcomers in the right direction (Fig. 4), but not to the exact distance of a food source (Fig. 3). In fact, more than $80 \%$ of the recruits found the control feeder placed very close to the nest. Food odor clearly plays a key role in searching by recruits, because a control feeder with scent different from the training scent is found much less than one with the training scent (Fig. 3). Plebeia tica behaves different from its congener $P$. droryana, which does not communicate direction (Lindauer and Kerr, 1958; Fig. 5). On the other hand, T. carbonaria (Nieh et al., 2000) behaves very similar and newcomers arrive at the right direction, but mostly on the closest of the feeders. Our data suggest that in $P$. tica the similarity in food odor between the training and control feeders is responsible for the discovery of nearby food sources that are not visited by trained bees.

The poor recruitment of $T$. angustula constrained the distance experiments. We found, however, clear evidence for direction communication (Fig. 4). This is in contrast to the suggestion of Lindauer and Kerr (1958) that this species only uses a general alarming of recruits without any communication of the location of the food source. At the time of our study, a natural pollen source, Cyperus rotondus, was available near the T. angustula nest. This may have led to a general alarming about the presence of a food source, and thus may have limited the recruitment to our feeders.

\subsection{What are the mechanisms for the indication of distance and direction?}

Our experiments show that the majority of the recruits in $T$. corvina and $P$. tica arrive at the feeder at the same time as the trained forager (Fig. 5). This suggests that scout bees guide newcomers by means of pilot flights the entire distance from the nest to the feeder. General alarming by means of sound and random zig-zag running (Lindauer and Kerr, 1958) and learning of the food odor inside the nest, complemented with piloting between nest and food source may be the mechanism that $P$. tica uses in food source location communication. It may work as follows: recruits follow the experienced forager outside the nest, but start searching for the food source as soon as they perceive the food odor they learned from the experienced forager inside 
the nest. In this way, they will find the same kind of food that the experienced forager found, but most likely the flower patch nearest to the nest in the same direction as the patch of the experienced bee. Our finding that a control feeder $10 \mathrm{~m}$ closer to the nest than the experimental feeder was found by similar numbers of recruits may indicate that near the control feeder some recruits started searching for that feeder, whereas others continued to follow the pilot to its food source.

Piloting can explain the arrival of one or two recruits together with the experienced forager, as in $P$. tica, but can it explain the arrival of large groups of recruits in $T$. corvina? Another species that uses piloting to guide groups of recruits to a food source, Scaptotrigona postica, additionally deposits a scent trail from the nest to the food source (Lindauer and Kerr, 1958). Although we eliminated scentmarks (including foot print) at the feeder as an orientation cue by regularly replacing the visited feeder with a clean one, the behavior of the experienced bees away from the feeder suggests that a scent trail may be used by $T$. corvina. Like the $S$. postica trail-layer, $T$. corvina recruiters made several short visits to the feeder and each time flew in the direction of the nest just before a group of recruits arrived at the feeder. Moreover, her behavior on the soil and vegetation near the feeder was similar to the scentmarking behavior described by Lindauer and Kerr (1958). Newcomers normally landed at the feeder only when an experienced bee was present although most of the time scent-marks were probably present on the soil and vegetation. The few groups of recruits that arrived without a pilot bee (easily identifiable by its thoracic paint mark) spread out in the neighborhood of the feeder and took a long time before they landed on the feeder. This confirms that local enhancement plays a role in landing decisions of newcomers (Slaa et al., 2003). Whether T. corvina uses a scent trail to bring recruits to a food source is currently under study.

\subsection{Why are these species different in recruitment and location communication?}

The wide range of recruitment communication strategies found in stingless bees makes them an excellent group to study the effect of coop- erative foraging strategies on resource partitioning in closely-related species. The simpler mechanisms, e.g. general alerting and piloting, have been regarded as more primitive than the more complex mechanisms that involve location communication (Lindauer, 1956; Lindauer and Kerr, 1958, 1960; Nieh et al., 2000). However, up to several dozen species that use different communication mechanisms tend to share most tropical habitats. This suggests that different strategies might be better seen as complementary and as adaptations to the exploitation of different food sources (Johnson, 1983; Slaa et al., 1997; Slaa, 2003). One factor that may influence the communication mechanism is colony size (Lindauer and Kerr, 1958). Species with large colonies, e.g. T. corvina, might benefit more from directing their foragers to the best food sources than species with smaller colonies because if all foragers from a large colony start searching randomly for food around the nest they will compete especially with their nest mates. Moreover, even if location communication is costly (in time spent recruiting or pheromone production) and not very efficient (e.g. Melipona panamica (Nieh and Roubik, 1995) and honey bees (Seeley, 1983)), sending out large numbers of recruits almost guarantees that at least some will find the excellent food source. Species with small colonies, e.g. P. tica and T. angustula, do not have enough foragers to guide recruits to the best food sources in their large flight range or to defend a food source against stronger rivals (Johnson, 1983; Slaa, 2003). If defending excellent food sources is beneficial (Johnson and Hubbell, 1974; Johnson, 1983), large colonies with more accurate location communication mechanisms would increase their harvest compared to similar species with less accurate communication. It is likely that the most accurate mechanism is laying a scent trail in combination with piloting (Lindauer and Kerr, 1958), which is probably used by $T$. corvina. This leads to a rapid increase of bees at the exact location (Figs. 3 and 4) and monopolization of the food source (Johnson, 1983; Slaa, 2003). The disadvantage of this strategy is evident, as equally profitable food sources available closer to the nest, and thus at lower exploitation costs, are bypassed completely (Fig. 3). The "less advanced", less accurate mechanisms, render better results under such conditions, 
because similar food sources nearer to the nest are found easily and exploited at lower cost than the far away food source communicated by the scout bee.

It is not completely clear to what extend differences in individual foraging behavior, e.g. local enhancement (Slaa et al., 2003), and in collective foraging, e.g. location communication (Lindauer and Kerr, 1958; Nieh and Roubik, 1995; this study) and aggressiveness (Johnson and Hubbell, 1974; Slaa, 2003), lead to general differences in resource use. Johnson (1983) identified four solitaries and four group foraging strategies of stingless bees and has some indication that these differences in strategies allow them to share resources by exploiting them at different times or different spatial densities. Further study may reveal whether the differences in recruitment intensities and location communication that we reported here for $T$. corvina, $P$. tica and $T$. angustula consistently lead to differential resource use.

\section{ACKNOWLEDGEMENTS}

We are grateful to Maricela Guerrero, Hester van Lier and Helen Martens for collaboration in collection of the field data and Jesús Espinoza for providing the nest of $P$. tica. We thank Judith Slaa for helpful comments on the manuscript. IAM and AF were supported by the Research Program of the Regional Stingless Beekeeping Project (PRAM-CINAT), which is financed by the Netherlands Organization for Cooperation in Higher Education (NUFFIC). JCB was supported through a TALENT-fellowship of the Netherlands Foundation for Scientific Research (NWO).

Résumé - Recrutement et communication de la localisation de la source de nourriture chez trois espèces d'abeilles sans aiguillon (Hymenoptera, Apidae, Meliponinae). Les mécanismes de communication au sein des abeilles sans aiguillon est très variable, aussi l'approche comparative est elle intéressante pour étudier l'écologie comportementale de la communication du butinage chez les Meliponinae. Nous avons analysé le comportement de recrutement et les systèmes de communication chez trois espèces d'abeilles sans aiguillon (Trigona corvina, Plebeia tica and Trigona (Tetragonisca) angustula) en relation avec la localisation de la source de nourriture. Nous avons dressé des abeilles à visiter un nourrisseur de sirop de sucre situé à $50 \mathrm{~m}$ et nous avons placé des nourrisseurs témoins identiques à des distances ou dans des directions variées par rapport au nid.
Nous avons montré que la distance comme la direction de la source de nourriture étaient communiquées très précisément chez $T$. corvina. Chez $P$. tica et $T$. angustula, seule la direction est communiquée. L'intensité du recrutement était élevé chez $T$. corvina $((3,12 \pm 2,5$ recrues par vol d'éclaireuse $)$ et bien plus faible chez $P$. tica $(0,11 \pm 0,17)$ et chez $T$. angustula $(0,07 \pm 0,04)$ (Fig. 1). Dans les expériences sur la distance avec $P$. tica, les nouvelles venues sont principalement arrivées sur le nourrisseur le plus proche du nid. Ce n'est que lorsque le nourrisseur témoin avait une odeur différente du nourrisseur test que la plupart des recrues ont trouvé celui-ci. T. angustula a recruté trop peu de recrues dans les expériences sur la distance pour tirer quelle que conclusion que ce soit. Chez les trois espèces les recrues sont arrivées en nombre significativement plus grand sur le nourrisseur test que sur le nourrisseur témoin placé dans la position opposée (test binomial sur les données groupées: $P<0,001$ pour $T c$ (5 essais) et $P<0,004$ pour $P t$ ( 8 essais), $P=0,006$ pour $\mathrm{Ta}$ (7 essais) ; Fig. 4). Lorsque nous avons placé le nourrisseur témoin à $90^{\circ}$ par rapport au nourrisseur test, les recrues sont arrivées en nombre significativement plus grand sur le nourrisseur test que sur le nourrisseur témoin chez $T$. corvina et $P$. tica (test binomial sur les données groupées : $P<0,001$, 2 et 8 essais respectivement ; Fig. 4).

Nous avons enregistré les heures exactes d'arrivée des abeilles dressées et des recrues dans les expériences de distance et de direction avec $P$. tica et $T$. corvina et dans des essais complémentaires avec $P$. tica (au total 11 essais avec $T c$ et 36 essais avec $P t$ ). La grande majorité des recrues arrivait en même temps, i.e. entre $4 \mathrm{~s}$ avant et $4 \mathrm{~s}$ après l'arrivée de l'abeille dressée (Fig. 5 ; Pt : 78,1 \% de 114 recrues ; Tc : $87,5 \%$ de 489 recrues). Ce résultat suggère que les abeilles éclaireuses pilotent les nouvelles venues sur toute la distance du nid au nourrisseur.

La gamme étendue des stratégies de communication du recrutement que l'on trouve chez les abeilles sans aiguillon fait de ce groupe un excellent modèle pour étudier l'influence des stratégies coopératives de butinage sur le partage des ressources chez des espèces étroitement apparentées. Les mécanismes les plus simples, tels que l'alerte et le pilotage, ont été considérés comme plus primitifs que les mécanismes plus complexes qui impliquent la communication de la localisation (Lindauer, 1956 ; Lindauer et Kerr, 1958, 1960 ; Nieh et al., 2000). Pourtant sous les tropiques, plusieurs douzaines d'espèces utilisent des mécanismes de communication variés et se partagent la plupart des habitats. Cela suggère qu'il vaut mieux considérer les différentes stratégies comme étant complémentaires et comme des adaptations à l'exploitation de différentes sources de nourriture (Johnson, 1983 ; Slaa et al., 1997 ; Slaa, 2003).

abeille sans aiguillon / communication / recrutement / vol pilote / Trigona / Plebeia 
Zusammenfassung - Rekrutierung und Kommunikation der Position von Futterquellen bei drei Arten von Stachellosen Bienen. In dieser Arbeit untersuchten wir das Rekrutierungsverhalten und die Kommunikationssysteme bei drei Arten von Stachellosen Bienen (Trigona corvina, Plebeia tica und Trigona (Tetragonisca) angustula) in Bezug auf die Lokalisierung der Futterquelle.

Wir trainierten Bienen auf eine $50 \mathrm{~m}$ entfernte Futterquelle mit Zuckerwasser und stellten identische Futterquellen in unterschiedlichen Entfernungen oder unterschiedlichen Richtungen vom Nest auf. Wir konnten zeigen, dass T. corvina sowohl die Entfernung als auch die Richtung der Futterquelle sehr genau anzeigt, bei $P$. tica und T. angustula hingegen wurde nur die Richtung der Futterquelle mitgeteilt. Die Rekturierungsintensität war bei $T$. corvina hoch $(3,12 \pm 2,5$ rekrutierte Bienen pro Suchbiene) und war wesentlich niedriger bei $P$. tica $(0,11 \pm 0,17)$ und auch bei $T$. angustula $(0,07 \pm 0,04)$ (Abb. 1). In den Entfernungsexperimenten mit $P$. tica kamen die meisten rekrutierten Bienen zu der am nächsten zum Nest hin plazierten Futterquelle. Nur wenn die Kontrollfutterquellen einen anderen Duft hatten als die korrekte Futterquelle, kamen die meisten Rekruten zum korrekten Futterplatz. In den Experimenten mit T. angustula war die Zahl der rekrutierten Bienen in den Entfernugnsexperimenten $\mathrm{zu}$ niedrig, um $\mathrm{zu}$ konkreten Schlussfolgerungen zu kommen. Bei allen drei Arten kamen signifikant immer mehr rekrutierte Bienen an der korrekten Futterquelle an als an der in der entgegengesetzten Richtung plazierten Kontrollfutterquelle (Binomialtest für gepoolte Daten: $P<0,001$ für Tc (5 Experimente), $P<0,004$ für $P t$ (8 Experimente) und $P=0,006$ für $T a$ (7 Experimente); Abb. 4). Wenn die Kontrollfutterquelle in einem $90^{\circ}$ Winkel zur korrekten Futterquelle plaziert war, kamen bei $T$. corvina und bei $P$. tica signifikant mehr rekrutierte Bienen zur korrekten Futterquelle als zum Kontrollplatz (Binomialtest für gepoolte Daten: in beiden Fällen $P<0,001$ bei 2, bzw. 8 Experimenten; Abb. 4).

Sowohl bei den Entfernungs als auch den Richtungsexperimenten mit $P$. tica und T. corvina, sowie bei einigen zusätzlichen Experimenten mit $P$. tica (insgesamt 11 Experimente für $T c$ und 36 Experimente für $P t$ ), registrierten wir die genauen Ankunftszeiten der trainierten und der rekrutierten Bienen. Die grosse Mehrzahl der rekrutierten Bienen kam zum gleichen Zeitpunkt an, d.h. 4 Sekunden vor, bzw. nach der trainierten Sammlerin (Abb. 5; 78,1 \% der 114 rekrutierten Bienen bei Pt und 87,5\% der 489 rekrutierten Bienen bei $T c$ ). Dies weist darauf hin, dass die Suchbienen die rekrutierten Bienen mittels Pilotflügen über die gesamte Distanz zwischen Nest und Futterplatz führen.

Die breite Skala der Kommunikationsstrategien für die Rekrutierung von Sammlerinnen bei Stachellosen Bienen macht diese zu einer hervorragenden Gruppe für Untersuchungen zum Effekt kooperativer Sammelstrategien im Hinblick auf die Ressourcenaufteilung bei nahverwandten Arten. Die einfache- ren Mechanismen, z.B. allgemeine Aufregung und Pilotflüge, werden als ursprünglicher angesehen als die komplexeren Mechanismen, die die Kommunikation der Position von Futterquellen beinhalten (Lindauer, 1956; Lindauer und Kerr, 1958, 1960; Nieh et al., 2000). In den Tropen benutzen jedoch mehrere Dutzend Arten unterschiedliche Strategien und teilen sich die meisten Habitate. Dies weist darauf hin, dass die unterschiedlichen Strategien besser als komplementär angesehen werden sollten und als Adaptationen an die Ausbeutung unterschiedlicher Futterquellen (Johnson, 1983; Slaa et al., 1997; Slaa, 2003).

Stachellose Biene / Kommunikation / Rekrutierung / Pilotflug / Trigona / Plebeia

\section{REFERENCES}

Aguilar I., Sommeijer M. (2001) The deposition of anal excretions by Melipona favosa foragers (Apidae: Meliponinae): behavioural observations concerning the location of food sources, Apidologie 32, 37-48.

Aguilar I., Briceño D. (2002) Sounds in Melipona costaricensis (Apidae: Meliponini): effect of sugar concentration and nectar source distance, Apidologie $33,375-388$.

Biesmeijer J.C., van Nieuwstadt M.G.L., Lukacs S., Sommeijer M.J. (1998) The role of internal and external information in foraging decisions of Melipona workers (Hymenoptera: Meliponinae), Behav. Ecol. Sociobiol. 42, 107-116.

Breed M.D., Stocker E.M., Baumgartner L.K., Vargas S.A. (2002) Time-place learning and the ecology of recruitment in a stingless bee, Trigona amalthea (Hymenoptera, Apidae), Apidologie 33, 251-258.

Esch H. (1967) Die Bedeutung der Lauterzeugung für die verständigung der stachellosen Bienen, $\mathrm{Z}$. Vergl. Physiol. 56, 199-220.

Esch H., Esch I., Kerr W.E. (1965) Sound: an element common to communication of stingless bees and to dances of the honey bee, Science 149, 320-321.

Frisch K. von (1967) The dance language and orientation of bees, Harvard Univ Press, Cambridge, MA.

Hölldobler B., Wilson E.O. (1990) The ants, Belknap Press of Harvard Univ Press, Cambridge, MA.

Hrncir M., Jarau S., Zucchi R., Barth F.G. (2000) Recruitment behavior in stingless bees, Melipona scutellaris and M. quadrifasciata. II. Possible mechanisms of communication, Apidologie 31, 93-113.

Hubbell S.P., Johnson L.K. (1978) Comparative foraging behavior of six stingless bee species exploiting a standardized resource, Ecology 59, 1123-1136.

Jarau S., Hrncir M., Zucchi R., Barth F.G. (2000) Recruitment behavior in stingless bees, Melipona scutellaris and $M$. quadrifasciata. I. Foraging at 
food sources differing in direction and distance, Apidologie 31, 81-91.

Johnson L.K. (1983) Foraging strategies and the structure of stingless bee communities in Costa Rica, in: Jaisson P. (Ed.), Social Insects in the tropics, Vol. 2, Univ. de Paris-Nord, pp. 31-58.

Johnson L.K., Hubbell S.P. (1974) Aggression and competition among stingless bees: field studies, Ecology 55, 120-127.

Kerr W.E. (1969) Some aspects of the evolution of social bees (Apidae), Evol. Biol. 3, 139-175.

Kerr W.E. (1994) Communication among Melipona workers (Hymenoptera: Apidae), J. Insect Behav. 7, 123-128.

Lindauer M. (1956) Über die Verständigung bei indischen Bienen, Z. Vergl. Physiol. 38, 512-557.

Lindauer M., Kerr W.E. (1958) Die gegenseitige Verständigung bei den stachellosen Bienen, Z. Vergl. Physiol. 41, 405-434.

Lindauer M., Kerr W.E. (1960) Communication between the workers of stingless bees, Bee World $41,65-71$.

Nieh J.C., Roubik D.W. (1995) A Stingless Bee (Melipona panamica) Indicates Food Location Without Using a Scent Trail, Behav. Ecol. Sociobiol. 37, 63-70.

Nieh J.C., Roubik D.W. (1998) Potencial mechanisms for the communication of height and distance by a stingless bee, Melipona panamica, Behav. Ecol. Sociobiol. 43, 387-399.

Nieh J.C., Tautz J., Spaethe J., Bartareau T. (2000) The communication of food location by a primitive stingless bee, Trigona carbonaria, Zool.-Anal. Complex Sy. 102, 238-246.

Nieh J.C., Contrera F.A.L., Ramírez S., ImperatrizFonseca V.L. (2003) Variation in the ability to communicate three-dimensional resource location by stingless bees from different habitats, Anim. Behav. 66, 1129-1139.

Nieuwstadt M.G.L., Ruano C.E. (1996) Relation between size and foraging range in stingless bees (Apidae, Meliponinae), Apidologie 27, 219-228.

Roubik D.W., Yanega D., Aluja S.M., Buchmann S.L., Inouye D.W. (1995) On optimal nectar foraging by some Tropical bees (Hymenoptera: Apidae), Apidologie 26, 197-211.

Seeley T.D. (1983) Division of labor between scouts and recruits in honeybee foraging, Behav. Ecol. Sociobiol. 112, 253-259.

Siegel S., Castellan N.J. (1988) Nonparametric statistics for the behavioral sciences, McGraw-Hill, New York.

Slaa E.J. (2003) Foraging ecology of stingless bees: from individual behaviour to community ecology, Elinkwijk, Utrecht, The Netherlands.

Slaa E.J., Nieuwstadt M.G.L., Pisa L.W., Sommeijer M.J. (1997) Foraging strategies of stingless bees (Apidae, Meliponinae): The relation between precision of recruitment, competition and communication, Acta Hortic. 437, 193-197.

Slaa E.J., Wassenberg J., Biesmeijer J.C. (2003) The use of field-based information in eusocial foragers: local enhancement among nestmates and heterospecifics in stingless bees, Ecol. Entomol. 28 , 369-379.

Sokal R.R., Rohlf F.J. (1981) Biometry (2nd ed.), Freeman, New York.

Wille A. (1969) A new species of stingless bee Trigona (Plebeia) from Costa Rica, with descriptions of its general behavior and cluster-type nest, Rev. Biol. Trop. 15, 299-313. 